\title{
POST-CLINICAL FOLLOW-UP OF SPINAL PATIENTS THROUGH DOMESTIC CHECK-UPS (KOBLENZ MODEL)
}

\author{
By H. D. Lang, W. DürR, J. Hoffmann, and R. Koeth \\ Köblenz, Germany
}

\begin{abstract}
One hundred spine-injured patients have been visited at their homes, examined and questioned about their medical and social situation. The medical conditions have improved, compared with a former similar check-up. But the tendency to work has decreased and is lagging behind other countries. Possible reasons are pointed out.
\end{abstract}

Key words: Follow-up; professional rehabilitation; complications; social conditions.

WiTH the ambulatory follow-up of spine-injured patients there is a discrepancy between the best possible care and reality. This is due to the behaviour of the patients themselves, the environment and the lack of experience of spinal injuries by general practitioners.

Our knowledge of the actual circumstances is based on visits to spinal patients in their homes. This has been performed since 1967 by a team consisting of a teacher of physical education, a rehabilitation assistant and a physician of the Koblenz special unit with financial support from industrial insurance organisations. We report on IOO visits since $\mathbf{I} 972$.

\section{TABLE I}

Tasks

Rehabilitation assistant

Physical Education Teacher

\section{Physician}

Construction changes of the flat, financing of physical aids, car, vocational help

Motivation and advice of sports activities, check of sports equipment, walking aids

Check-up of medical situation, recommendation for the family doctor, indication for re-admission

\section{TABLE II}

Questions of interest

Intensity and quality of medical care at home

Family care

Family and financial situation

Job

Participation in sports activities

Possibility of vacation

Private car

Daily routine 


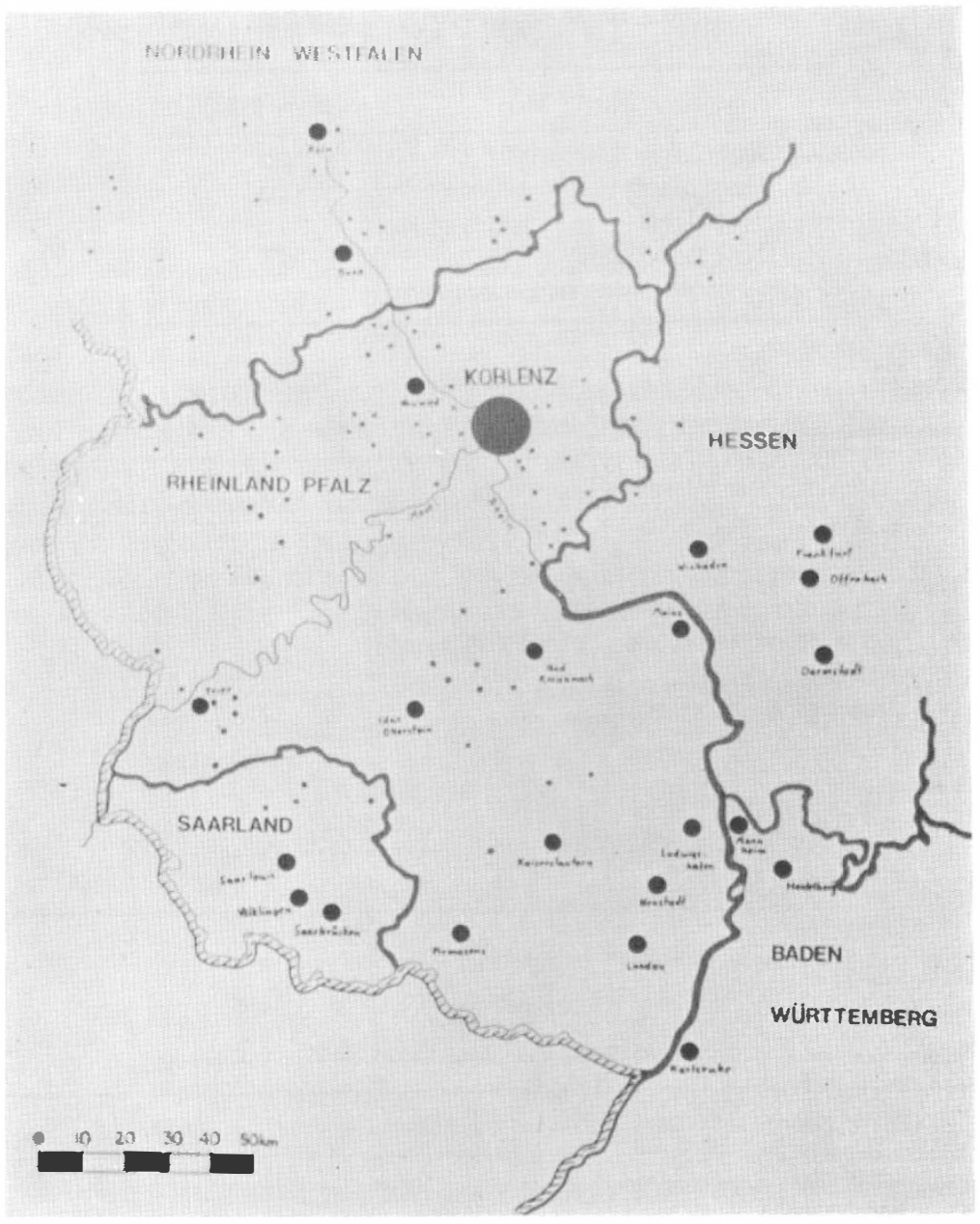

FIG. I

Geography of visits.

The following observations were made: the general practitioner's help is mostly asked for urinary tract infections. It seems that the most difficult problem is the technique of sterile sampling of urine. The family supply urine for examination out of the urinal. Urine is often examined only for bacteria by microscope whereas control of $\mathrm{pH}$, antibiogramm and measuring of residual urine is omitted for technical or time reasons.

TABLE III

\begin{tabular}{lc}
\hline Urinary check-up in general & $(\mathrm{n}=\mathrm{IOO})$ \\
\hline Every 4-6 weeks (as recommended) & 42 \\
Quarterly & 8 \\
Semi-annual & 24 \\
None & 26 \\
\hline
\end{tabular}


TABLE IV

\begin{tabular}{lc}
\hline Use of walking aids & $(\mathrm{n}=\mathrm{IOO})$ \\
\hline Regularly & 20 \\
Irregularly & 10 \\
Not used & 32 \\
Not necessary & 38 \\
(Tetraplegics or incomplete) & \\
\hline
\end{tabular}

TABLE V

\begin{tabular}{lr}
\hline Medical complications & $(\mathrm{n}=\mathrm{IO0})$ \\
\hline Small sores & $\mathrm{I} 5$ \\
Large sores & 4 \\
High blood pressure (over I50 mmHg) & 5 \\
Low blood pressure (below I00 mmHg) & 8 \\
Crural oedemata & 3 \\
Mis-use of medicaments & $\mathrm{I}$ \\
Purulent toes & $\mathrm{I}$ \\
Dysaesthesia arm & $\mathrm{I}$ \\
Ulcus cruris & $\mathrm{I}$ \\
Deterioration of urination and bowel movement & I \\
\hline
\end{tabular}

TABLE VI

Professional rehabilitation

\begin{tabular}{lccc}
\hline Literature & Author & Year & $\%$ \\
\hline England $\}$ & quoted from Meinecke & 80 \\
Germany $\}$ & & I7 \\
Germany Koblenz & Lang et. al. & I979 & 20 \\
\hline
\end{tabular}

The vocational rehabilitation in Germany is lagging behind other countries. Possible reasons for inability to work are:

Fear of cuts in pension

Lack of self-confidence

Concern by family

Lack of employer's understanding regarding the ability of the injured

Employer's concern in the pension situation

Unfavourable situation regarding employment

Local distance to place of employment

Insufficient adaptation of working place

Failure of re-training measures (separation from family, lack of skills)

Lack of motivation to work 
In our sample the following reasons were mentioned:

TABLE VII

Impeding reasons for work

Mainly rural area

Age

Kind of injury

According to Guttmann and Meinecke the number of divorces in spinal patients does not exceed the rate among the healthy population. Among our Ioo spinal-cord-injured patients there were only 2 divorced persons. However, quite a number of couples would be divorced if the financial situation for married couples was not as generous as it proved to be.

DM 4.000 .

The monthly total income of our population ranges between DM 1.000 and

TABLE VIII

\begin{tabular}{cc}
\hline Total income in DM & $(\mathrm{n}=\mathrm{I00})$ \\
\hline Under 1.000 & 5 \\
I.000 to 2.000 & 36 \\
2.000 to 3.000 & 44 \\
3.000 to 4.000 & I0 \\
Over 4.000 & 5 \\
\hline
\end{tabular}

TABLE IX

\begin{tabular}{lc}
\hline Social environment & $(\mathrm{n}=\mathrm{I00})$ \\
\hline Private home & 72 \\
At their parents & 4 \\
Flat adapted to the disabled & 24 \\
Private car & 72 \\
Vacation & 38 \\
No vacation any more & 62 \\
\hline
\end{tabular}

TABLE X

Changes 1970-1979 own sample \%

\begin{tabular}{lcc}
\hline & $\begin{array}{c}\text { Meine I970 } \\
\mathrm{n}=9 \mathrm{I}\end{array}$ & $\begin{array}{c}\text { Lang } \text { et al., I979 } \\
\mathrm{n}=\text { I00 }\end{array}$ \\
\hline Sores & 25 & $\mathrm{I} 9$ \\
Urethral fistulas & 6 & 0 \\
Private car & 56 & 72 \\
Ability to work & 43 & 20 \\
Sports activities & 42 & 32 \\
Walking aids not used & $\mathrm{I3}$ & 32 \\
\hline
\end{tabular}


According to Vögtle-Junkert and Zureck, in Germany only 2.7 per cent out of I5 000 spinal-cord-injured patients confined to wheel chairs, are integrated in sports groups for the disabled. In our sample 32 participated in sports clubs for the disabled.

\section{RÉSUMÉ}

De 1973 à 1979 on a examiné par contre-visite chez eux cent malades de section traversale traumatique en leur demandant la situation médicale et sociale. Par comparaison à de pareilles contrôles antérieures leur situation médicale en somme a amélioré tandis que leur capacité de travailler a Par la suite on va démontrer les causes de ce développement.

\section{ZUSAMMENFASSUNG}

IOO traumatisch Querschnittsgelähmte wurden von 1973-1979 zu Hause aufgesucht, nachuntersucht und über ihre medizinische und soziale Lage befragt. Während sich der medizinische Zustand im Vergleich zu einer früheren ähnlichen Untersuchung insgesamt gebessert hat, hat die Berufstätigkeit abgenommen. Die möglichen Gründe hierfür werden aufgezeigt.

\section{REFERENCES}

MeINE, E. (1970). Spezielle Fürsorge für Querschnittsgelähmte an ihrem Wohnort, Berufsgenossenschaft 2.

MEINECKE, F. W. (I965). Soziale und psychologische Fragen bei Querschnittsgelähmten Zbl. Chir. 90, 951-963.

MeINECKE, F. W. (I967). Traumatische Querschnittslähmungen Problematik der Behandlung. Med. Klinik, 62, 455-460.

VögTLE-JUKNERT, U. \& ZURECK, U. (1973). Sport als Rehabilitationsfaktor bei Querschnittsgelähmten Öff. Gesundh. - Wesen, 35, 7 1 7-725. 